Journal of Vocational and Career Education

UNNES

\title{
Pengembangan Media Informasi Pravokasional SMK bagi Siswa SMP di Kota Gorontalo
}

\author{
Muthia $^{1)}$, Djuniadi ${ }^{2)}$, I Made Sudana ${ }^{2)}$ \\ 1) Dinas Pendidikan Gorontalo, Indonesia \\ ${ }^{2)}$ Prodi Pendidikan Kejuruan, Pascasarjana, Universitas Negeri Semarang, Indonesia
}

\section{Info Artikel Abstrak}

Sejarah Artikel:

Diterima Oktober 2016

Disetujui April 2017

Dipublikasikan Juli

2016

\section{Keywords:}

Media Informasi;

Pravokasional; web;

Program Studi SMK
Tujuan dari penelitian ini yaitu menghasilkan produk media informasi pravokasional untuk siswa SMP, mengetahui kevalidan media informasi pravokasional dalam memberikan pengetahuan dan pemahaman kepada siswa SMP serta mengetahui kepraktisan penerapan media informasi pravokasional dalam memberikan pengetahuan dan pemahaman pada siswa SMP untuk melanjutkan studi ke SMK. Metode yang digunakan dalam penelitian ini yaitu Research and Development. Hasil penelitian ini menjelaskan dengan jenis media informasi berbasis WEB dapat diakses dengan mudah oleh pengguna yaitu siswa SMP. Hasil validasi materi dan validasi media dari masing-masing pakar menyebutkan persentase kevalidan materi sebesar $77 \%$ dan persentase kevalidan media sebesar $82 \%$. Ini menyimpulkan bahwa pengembangan media informasi pravokasional "Sangat Valid". Kepraktisan dari produk ini sebesar 34,5 dan memiliki kriteria sangat baik. Simpulan dari penelitian ini adalah media informasi pravokasional yang dikembangkan dinyatakan valid dan layak menurut penilaian pakar. Media informasi pravokasional untuk siswa SMP yang dikembangkan memiliki nilai keefektifan dan kepraktisan yang tinggi, karena media tersebut dapat membantu siswa dalam memahami dan mengetahui program studi SMK secara mandiri.

\begin{abstract}
The purpose of this study was to produced pre-vocational information media product for junior high school students, to found out pre-vocational information media in giving understanding and knowledge for junior high school students, and also to find out in applying pre-vocational information media in giving understanding and knowledge for junior high school to continue their study at vocational school. Research and development method was used in this study. The result of this study explained the kinds of WEB based information media. Which could be accessed easily by junior high school students. The percentage of material and media validity from the expert was $77 \%$ and the percentage of media validity was $82 \%$. It could be summarized that pe-vocational media information was very valid. Practically of this product was 34,5 and had good criteria. The result of this pre-vocational information media study which could be developed was valid and suitable based on expert opinion. Pre-vocational information media for junior high school students had practically and effectively higher value, because that media could help the student in understanding the study program at vocational school by them selves.
\end{abstract}




\section{PENDAHULUAN}

Informasi yang diperoleh siswa SMP masih sangat minim mengenai jurusan-jurusan yang ada di SMK. Menurut Calik (2013) bahwa pemanfaatan teknologi dalam pembelajaran mampu meningkatkan efektivitas pembelajaran karena dapat menjadikan siswa lebih aktif dan percaya diri. Pemanfaatan teknologi saat ini yang sangat menjamur dikalangan siswa SMP adalah teknologi internet. Untuk menggunakan teknologi internet pada tempatnya dalam bidang informasi pravokasional, dibutuhkan media informasi yang menyuguhkan pendidikan pravokasional. Sekarang ini banyak media informasi SMK berbasis web dalam bentuk sistem informasi yang belum bisa menyuguhkan program keahlian SMK secara mendetail. Pengetahuan dasar tentang program keahlian SMK sangat dibutuhkan siswa SMP untuk menentukan program keahlian yang diingikannya.

Secara spesifik, untuk SMK di Kota Gorontalo sendiri terdapat 9 Sekolah Menengah Kejuruan masing-masing 5 SMK Negeri dan 4 SMK Swasta. Dari sembilan sekolah ini beberapa sekolah sudah mempunyai sistem informasi berbasis web yang biasa digunakan oleh sekolah untuk mempromosikan sekolahnya. Tetapi dari beberapa media informasi yang dimiliki SMK, terdapat beberapa Website yang sudah tidak aktif lagi dan Website yang tersedia hanya menampilkan profil sekolah sebagaimana sistem informasi sekolah pada umumnya. Website yang ada tidak menampilkan inti dari jurusan yang ada di sekolah itu dan jenjang karir yang akan diperoleh oleh siswa jika memasuki jurusan yang tersedia. Selain website terdapat juga media yang menjadi perantara dalam mengembangkan karir yaitu pelayanan cybercounseling. Pelayanan cybercounseling juga merupakan sebuah alternatif untuk membantu menyelesaikan masalah, dimana proses pemberian bantuan psikologis dari seorang konselor yang profesional kepada seorang konseli yang memiliki masalah dan tidak mampu menyelesaikan masalahnya sendiri (Hernawati \& Djuniadi, 2016). Permasalahan ini menjadi alasan diberikannya media informasi pravokasional berbasis web untuk siswa SMP karena informasi diperlukan bagi individu sebagai pertimbangan bagi arah pengembangan diri, dan sebagai dasar pengambilan keputusan. Salah pilih sekolah, salah pilih pekerjaan, seringkali menjadi akibat dari kurangnya infomasi. Digunakannya media untuk memudahkan siswa memahami informasi jurusan yang diberikan sehingga siswa dapat tertarik dengan media informasi pravokasional yang biasanya dilakukan hanya dengan ceramah namun dengan penggunaan media berbasis web dapat di akses di mana dan kapan saja.

Penggunaan media yang berkaitan dengan multimedia dapat dilakukan dalam berbagai bidang salah satunya cara memperoleh informasi, menggunakan internet dan berbagai software untuk mencari informasi. Menurut Li \& Ozsu (2002) "As multimedia technology is becoming increasingly powerful and pervasive, we begin to see some real products available in the market, including search engines, graphics software and education systems". Multimedia adalah alat, metoda dan pendekatan yang digunakan untuk membuat komunikasi diantara pendidik dengan peserta didik selama proses pembelajaran, sehingga menjadi lebih menarik (Munir, 2013). Informasi untuk pravokasional siswa SMP dibutuhkan dengan memberikan pemahaman tentang program studi keahlian yang terdapat di SMK serta pekerjaan yang dapat diperoleh. Seperti yang dikemukakan oleh Ferrari (2015) yaitu "it is possible to hypothesize a progressively increasing indepth exploration from childhood to adolescence, together with an increase in occupational information and its integration with previous knowledge".

Oliver (2001) menggolongkan alat untuk kursus berbasis web menjadi dua kategori yaitu alat pengembangan untuk membuat dan menyampaikan konten online dan alat-alat belajar aktif bagi siswa untuk terlibat dalam pengolahan informasi tingkat tinggi (contoh : menganalisis, mensistesis, mengevaluasi). Website merupakan media yang memiliki jangkauan sangat luas (Regional-Internasional). Pemrograman Web dapat dilakukan melalui 
online code editor di mana peserta didik dapat memperoleh petunjuk dan bantuan tambahan dengan mudah dalam mengakses sistem tersebut (Elgamal, Abas \& Toner, 2013).

Pendidikan kejuruan atau pendidikan vokasional merupakan jenjang pendidikan yang selalu dinamis dalam melakukan perubahan kurikulum pendidikan sesuai dengan pertumbuhan pasar kerja dan beradaptasi dengan perkembangan ilmu pengetahuan dan teknologi. Menurut Pavlova (2009) dengan pertimbangan bahwa aktivitas ekonomi sangat ditentukan adanya perubahan teknologi yang cepat pada masa mendatang, maka orientasi pendidikan vokasi diarahkan menjadi pendidikan bekerja (work education) atau pendidikan teknologi (technology education).

Tujuan dari penelitian ini adalah menghasilkan pengembangan produk media informasi pravokasional untuk siswa SMP, mengetahui kevalidan media informasi pravokasional dan mengetahui kepraktisan penerapan media informasi pravokasional dalam memberikan pengetahuan serta pemahaman siswa SMP untuk melanjutkan studi ke SMK.

\section{METODE}

Metode penelitian yang digunakan adalah metode penelitian dan pengembangan atau Research and Development (R\&D). Secara konseptual, sugiyono (2015) menyatakan bahwa penelitian dan pengembangan dapat diartikan sebagai cara ilmiah untuk meneliti, merancang, memproduksi dan menguji validitas produk yang telah dihasilkan. Adapun prosedur penelitian dalam pengembangan media informasi pravokasional untuk siswa SMP tersebut meliputi : (a) Tahapan Penelitian Awal dan Pengumpulan Informasi; (b) Analisis Sistem; (c) Pengembangan dan Perancangan Media; (d) Validasi Ahli; (e) Revisi Media; (f) Uji Coba Produk Media.

\section{HASIL DAN PEMBAHASAN}

Informasi yang diperoleh oleh siswa SMP kelas IX dalam pendidikan pravokasional berupa informasi yang biasa dilakukan oleh SMK yang berkunjung ke sekolah-sekolah menengah pertama untuk mempromosikan SMK mereka. Kebanyakan siswa SMP masih hanya belum paham betul dengan prodi yang ditawarkan oleh SMK, mereka menganggap prodi yang paling popular adalah prodi yang bisa di pilih nanti jika memilih untuk masuk ke SMK. Berdasarkan dari beberapa fakta yang diperoleh dari observasi awal, dapat disimpulkan bahwa pembelajaran dikelas yang dilakukan secara konvensional dan kunjungan SMK belum cukup untuk memberikan pengetahuan dan pemahaman siswa terhadap program studi yang ada di SMK. Karena setiap SMK yang melakukan promosi di SMP, hanya sekolah kejuruan tertentu dan tidak semua SMK yang melakukannya. Pendidikan pravokasional tidak akan terserap secara sempurna apabila tidak diberikan bimbingan karir maupun informasi yang menggunakan media untuk dapat mengembangkan pengetahuan mereka terhadap pendidikan pravokasional.

Dalam tampilan awal media informasi pravokasional ini terdapat beberapa menu utama yaitu Beranda, Tentang SMK, Program studi, SMK Di Gorontalo dan Kontak. Di halaman awal atau biasa disebut dengan beranda web, spesifikasi yang ada di halaman ini antara lain ada beberapa header gambar yang terdapat pada slide. Kemudian tampilan dibawahnya terdapat informasi awal web pravokasional serta gambar SMK yang ada di Kota Gorontalo.

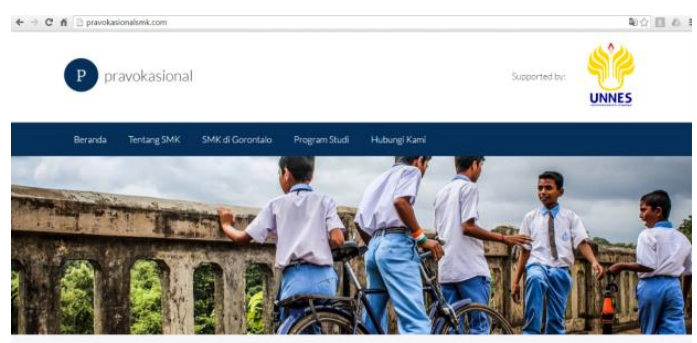

Gambar 1. Jendela Utama Media Informasi Pravokasional 
Menu SMK Di Gorontalo dalam media Informasi Pravokasional ini menyuguhkan beberapa foto-foto dokumentasi dari SMK yang ada di kota Gorontalo. Tujuannya agar siswa SMP bisa mengetahui gambaran Sekolah Menengah Kejuruan yang ingin diminatinya. Berikut tampilan menu "SMK di Gorontalo" pada gambar 2:

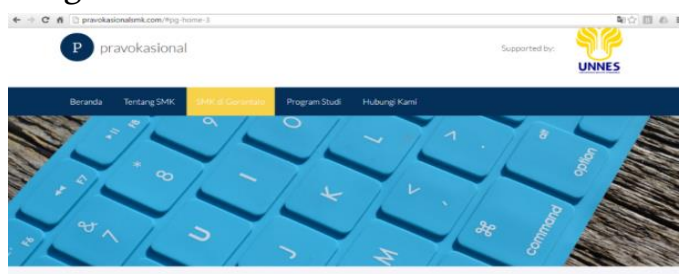

Gambar 2. Tampilan Menu "SMK di Gorontalo"

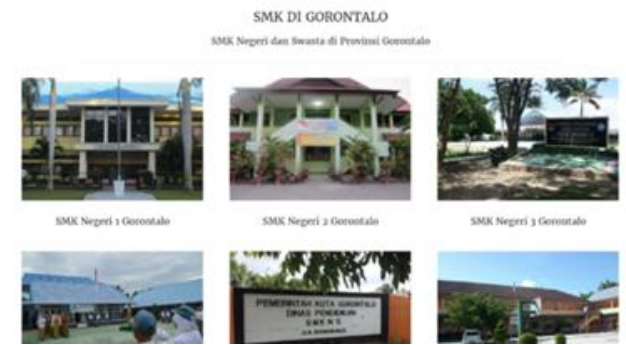

Gambar 3. Tampilan "SMK di Gorontalo"

\section{Validasi Ahli}

Hasil validasi penilaian dari ahli materi dapat dilihat pada tabel 1 adalah sebagai berikut

Table 1. Hasil Validasi Ahli Materi

\begin{tabular}{lllll}
\hline Aspek isi yang di ukur & \multicolumn{2}{l}{ Skor Validator } & \multirow{2}{*}{ Rata-rata } & \multirow{2}{*}{ Kriteria } \\
\cline { 2 - 3 } & Validator 1 & Validator 2 & & \\
\hline Kelayakan Penyajian Media Informasi Pravokasional & 3.13 & 3.13 & 3.13 & Sangat Valid \\
Kelayakan Isi Informasi Pravokasional & 3 & 3.1 & 3.05 & Sangat Valid \\
Total Rata-rata & & & 3.09 & Sangat Valid \\
\hline Rata-rata nilai $=3.09$ & & & \\
Rata-rata nilai $\max =4$ & & & \\
Persentase kelayakan $=\frac{\mathbf{3 . 0 9}}{\mathbf{4}} \times \mathbf{1 0 0} \%=\mathbf{7 7} \%$ & & & \\
\hline
\end{tabular}

Tabel 1 menunjukkan skor rata-rata hasil validasi materi adalah 3,09 yang menunjukkan media informasi pravokasional ini sangat valid dalam segi isi materi. Persentase keefektifan menunjukkan nilai persentasi $77 \%$. Sehingga sesuai daftar persentase pencapaian nilai tersebut termasuk pada kategori "Sangat Valid". Hasil validasi dari penilaian ahli media adalah sebagai berikut pada tabel 2 :

Tabel 2. Hasil Validasi Ahli Media

\begin{tabular}{|c|c|c|c|c|c|}
\hline \multirow[t]{2}{*}{ Aspek isi yang di ukur } & \multicolumn{3}{|c|}{ Skor Validator } & \multirow[t]{2}{*}{ Rata-rata } & \multirow[t]{2}{*}{ Kriteria } \\
\hline & Validator 1 & Validator 2 & Validator 3 & & \\
\hline Tampilan Media (Interprobability) & 3.75 & 3.2 & 3.4 & 3.4 & Sangat Valid \\
\hline Usabilitas (Usability) & 3.3 & 3.1 & 3.2 & 3.1 & Sangat Valid \\
\hline Kompabilitas (Portability) & 3 & 3 & 3.7 & 3.4 & Sangat Valid \\
\hline Total Rata-rata & & & & 3.3 & Sangat Valid \\
\hline \multicolumn{6}{|l|}{ Rata-rata nilai $=3.3$} \\
\hline \multicolumn{6}{|l|}{ Rata-rata nilai $\max =4$} \\
\hline \multicolumn{6}{|c|}{ Persentase kelayakan $=\frac{3.3}{4} \times \mathbf{1 0 0} \%=\mathbf{8 2} \%$} \\
\hline
\end{tabular}

Skor rata-rata dari hasil validasi ahli media adalah 3.3 yang menunjukkan media informasi pravokasional ini valid dalam segi media informasi. Persentase kelayakan menunjukkan nilai persentase sebesar $82 \%$. Sehingga, sesuai daftar persentase pencapaian nilai tersebut termasuk dalam kategori "Sangat Valid". Dapat disimpulkan media informasi pravokasional yang telah dikembangkan dapat dikatakan berkualitas sebagai media informasi pravokasional untuk siswa SMP.

Hasil tanggapan media informasi pravokasioanl terhadap siswa SMP diperoleh dari angket yang disebar kepada 33 siswa SMP Negeri 1 Gorontalo, 27 siswa SMP Negeri 6 dan 29 siswa SMP Negeri 13 Gorontalo, sebagai berikut: 


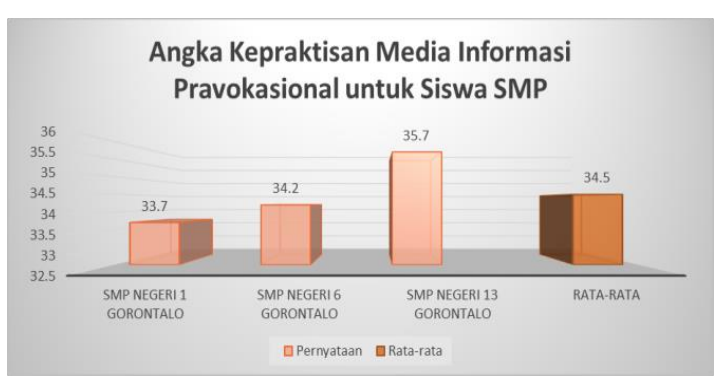

Gambar 3. Rata-rata Kepraktisan Media Informasi Pravokasional untuk Siswa SMP

Hasil akhir dari uji kepraktisan media informasi pravokasional menjelaskan bahwa siswa SMP yang berminat dalam mengetahui dan memahami SMK dan program studi SMK berada pada sekolah yang letak geografisnya berada jauh dari Kota Gorontalo dan belum mempunyai fasilitas internet yang memadai. Media informasi pravokasional ini sangat dibutuhkan oleh siswa-siswa SMP khususnya sekolah yang berada pada daerah yang belum semuanya terjangkau oleh internet. Hal ini bisa menjadi perhatian besar untuk pemerintah, bahwa pemerataan infrastruktur sekolah sangat dibutuhkan demi membangun generasi muda yang siap bersaing dalam dunia kerja.

Pengembangan media informasi pravokasional untuk siswa SMP yang dihasilkan telah sesuai dengan langkah-langkah penelitian pengembangan. Dilakukan revisi berdasarkan evaluasi dan saran oleh ahli media dan ahli materi dan kemudian di laukan uji efektifitas maka dihasilkanlah sebuah produk akhir media informasi pravokasioal yang efektif dan mudah digunakan oleh siswa maupun user sabagai salah satu sumber perolehan informasi tentang program studi yang ada di SMK Provinsi Gorontalo.

Sesuai dengan penelitian yang dilakukan oleh Liu, McMahon \& Watson (2015) tentang pemantapan keterampilan yang dikembangkan dimasa kecil dapat berdapak pada perkembangan karir masa depan. Pada penelitiannya Liu menguji bagaimana orang tua mempengaruhi aspirasi karir anak-anak mereka di daratan China dilihat dari kedua orang tua dan perspektif anak-anak. Dikaitkan dengan penelitian ini bahwa lingkungan keluarga menjadi salah satu pengaruh dalam menentukan karir anak-anak pada umumnya, dengan memberikan pengetahuan awal tentang pendidikan pravokasional untuk siswa SMP maka siswa tersebut dapat mengetahui secara dini informasi pravokasional khususnya program studi yang ada di SMK.

Hasil pengamatan awal di lapangan dan wawancara kepada kepala sekolah dari SMP N 1 Gorontalo, SMP N 6 Gorontalo serta SMP N 13 Gorontalo mengenai kondisi pengenalan SMK, diketahui bahwa pengenalan SMK dilakukan dengan menggunakan cara promosi dari SMK itu sendiri. Diartikan bahwa pengenalan SMK untuk siswa SMP masih dilakukan oleh SMK yang ingin mempromosikan SMK tanpa ada pembelajaran ataupun informasi yang diberikan oleh pihak SMP. Melihat fenomena saat ini dan dikaitkan dengan berkembangnya teknologi, guru mengharapkan adanya media informasi maupun media pembelajaran yang dapat digunakan di berbagai kesempatan atau yang disebut dengan media informasi interaktif. Hal ini didasarkan pada internet yang sudah menjadi kebutuhan dalam pembelajaran, dimana seluruh siswa SMP juga sudah sangat membutuhkan internet. Hasil observasi yang diperoleh, maka diperlukan suatu media informasi yang sesuai dengan kebutuhan. Website merupakan media yang memiliki jangkauan sangat luas (Regional-Internasional). Pemrograman Web dapat dilakukan melalui online code editor di mana peserta didik dapat memperoleh petunjuk dan bantuan tambahan dengan mudah dalam mengakses sistem tersebut (Elgamal, Abas \& Toner, 2013). Media informasi pravokasional berbasis WEB yang digunakan adalah media informasi yang dapat memberikan informasi tentang SMK juga Program Studi yang ada di SMK yang dapat di akses dimanapun menggunakan internet.

Hasil pengembangan media informasi pravokasional untuk siswa SMP ini dinyatakan efektif untuk digunakan dalam memberikan informasi SMK dan program studi yang ada di SMK se Kota Gorontalo. Dari beberapa penelitian yang sudah dilakukan sebelumnya, dapat diambil kesimpulan bahwa pemberian informasi karir sejak dini kepada siswa SMP 
sangatlah di perlukan. Melihat dari berbagai penelitian yang sudah dilakukan, keunggulan dari penelitian yaitu memberikan informasi pravokasional khususnya Sekolah Menengah Kejuruan beserta Program Studi kepada siswa SMP dengan menggunakan Website yang dapat diakses di mana dan kapan saja oleh siswa.

\section{SIMPULAN}

Bentuk media informasi pravokasional yang dikembangkan dan dihasilkan adalah berupa media informasi pravokasional berbasis web yang berisi tentang pengenalan awal SMK serta program studi yang ada di SMK Kota Gorontalo. Media informasi pravokasional yang dikembangkan dinyatakan valid dan layak menurut penilaian pakar. Media informasi pravokasional untuk siswa SMP yang dikembangkan memiliki nilai keefektifan dan kepraktisan yang tinggi, karena media tersebut dapat membantu siswa dalam memahami dan mengetahui program studi SMK secara mandiri.

\section{DAFTAR PUSTAKA}

Calik, M. 2013. Effect of Technology-Embedded Scientific Inquiry on Senior Science Student Teachers Self-Efficacy. Eurasia Journal of Mathematics, Science \& Technology Education. 9(3), 223-232.
Elgamal, A.F., Abas, H.A, \& Baladoh, E.S.M. 2013. An Interactive e-Learning System for Improving Web Programming Skills. Educational Information Technologi. 18, 29-46.

Ferrari, L. dkk. 2015. Career Exploration and Occupational Knowladge in Italian Children. International Journal for Educational and Vocational Guidance. 15(2), 113-130.

Hernawati, L., \& Djuniadi. 2016. Layanan Cybercounseling, Sebuah Alternatif untuk Membantu Menyelesaikan Masalah. Psikodimensia Journal. 15(1), 179).

Li, Q., \& Ozsu, M.T. 2002. Editorial : Introduction to Web Media Information System. World Wide Web Journal Internet and Web Information System. 5(2), 179-180.

Liu, J., McMahon, M., \& Watson, M. 2015. Parental Influence on Mainland Chines Children's Career Aspirations : Child and Parental Perspectives. International Journal Education Vocational Guidance. 15(2), 1-2.

Munir. 2013. Multimedia Konsep \& Aplikasi dalam Pendidikan. Bandung : Alfabeta.

Oliver, K. 2001. Recommendations for Student Tools in Online Course Management Systems. Journal of Computing in Higher Education. 13(1) : 47-70.

Pavlova, M. 2009. Technology and Vocational Education for Sustainable Development. Australia: Spinger.

Sugiyono. 2015. Metode Penelitian Pendidikan, Pendekatan Kualitatif, Kuatitatif dan $R \& D$. Bandung : Alfabeta. 